\author{
V.I. Shupeniuk ${ }^{1}$, S.V. Mamykin ${ }^{2}$, T.N. Taras ${ }^{1}$, M.P. Matkivskyi ${ }^{1}$, \\ O.P. Sabadakh ${ }^{1}$, O.M. Matkivskyi ${ }^{1}$
}

\title{
Structure and Morphology of Anthraquinone-Based Triazene Films on Silicon Substrate
}

\author{
${ }^{I}$ Vasyl Stefanyk Precarpathian National University, Ivano-Frankivsk, Ukraine, vasyl.shupeniuk@pnu.edu.ua \\ ${ }^{2} V$. Lashkaryov Institute of Semiconductor Physics, NAS of Ukraine, Kyiv, Ukraine, smamykin@gmail.com
}

An optimal deposition method of anthraquinone-based triazenes on silicon substrate was selected. This allowed to create a nanometer film that can be used as dielectric aromatic buffer layers. A morphological research of triazene films shows the existence of delocalized globular anthraquinone macromolecular microformation on the background of triazene uneven layers. The oxidized surface of silicon substrate provides better conditions for triazene films deposition than those without the oxide. This is caused by distribution of electron density in triazene which creates an additional $\mathrm{Si} / \mathrm{SiO}_{2}$ coupling system and by presence of voluminous aromatic substituents which impairs the uniformity of film deposition and reduces its thickness.

Keywords: triazene films, anthraquinone, electron density, anthraquinone-2-diazonium salt, silicon substrate.

Received 24.01.2020; accepted for publication 15.03.2020.

\section{Introduction}

There is a big scientific interest in researching organic triazene polymers in recent years [1-2]. This is mainly caused by high photosensitivity of triazene group $(\mathrm{N}-\mathrm{N}=\mathrm{N}-)$, which might be increased under the influence of different radiations. A variety of physical and chemical method (ion bombardment, thermal annealing, ultraviolet, hydrogenation, oxidation) allow to effectively change wettability and adhesion of triazenes in nanostructural films.

Li Hai-Ying and Ley Liang-Cai described a Langmuir-Blodgett synthesis of new organic ultrathin films with thin-layer structure, which include 9,10anthraquinone azo compounds with long alkyl chains and specific properties like electrochromism and photochromism. Azo compounds were produced of 2aminoanthraquinone that was dissolved in concentrated sulfuric acid, diazotized with sodium nitrite solution and then azocoupled with phenol:<smiles>Nc1ccc2c(c1)C(=O)c1ccccc1C2=O</smiles>

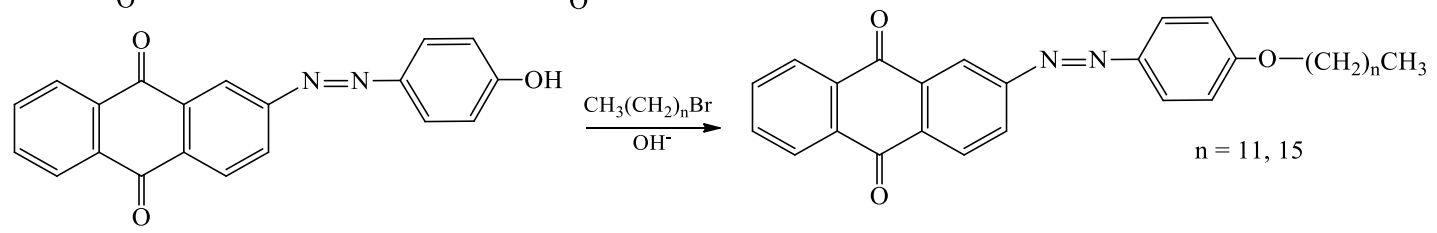


Zhang Yixing [8] with co-authors was investigating the possibility of 9,10-anthraquinone azo compounds usage (with layer thickness $85 \mathrm{~nm}$ ) in storage devices. This compound was produced by classical reaction of azo coupling: 9,10- anthraquinone-1,4-diazonium was spilled into amine solution in ethanol:

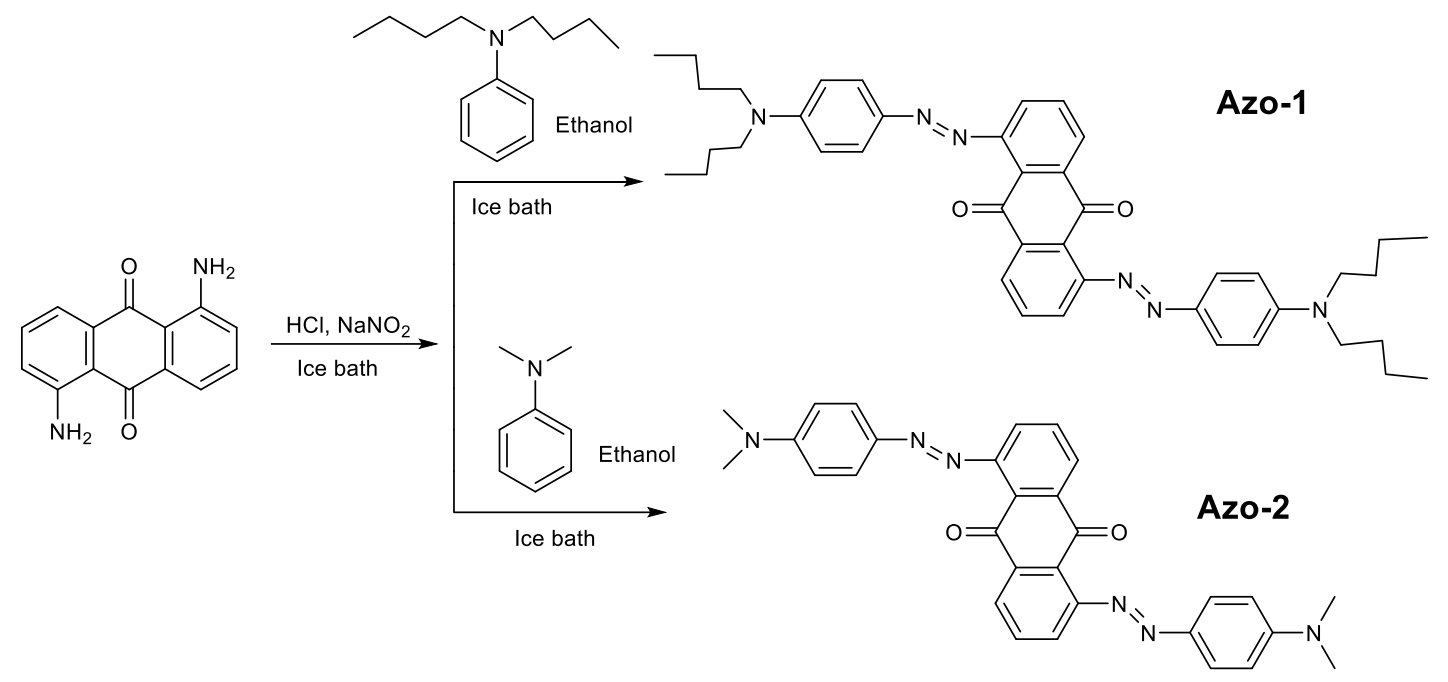

The electroactive layers vacuum deposited by Azo-1, which contained the double conjugated backbone and longer alkyl chains, could retain invariable film quality from room temperature to $125^{\circ} \mathrm{C}$, and the corresponding devices show excellent ternary data-storage performance, while the "counterpart" molecules Azo-2, exhibit poor film stability and even have no typical electrical characteristics. The result shows that suitable length of the conjugated backbone and alkyl chain could lead to a well $\pi-\pi$ stacked film [8-9].

This paper investigates the peculiarities of the deposition of triazine films on the oxidized silicon substrate by microphotography and spectral ellipsometry. We previously produced and described [10-12] the triazene samples (1-5) production. We used 1anthraquinone phosphonate acid (6) for comparison.

\section{Experimental}

Triazenes of the anthraquinone series (1-5) and 1-anthraquinone phosphonate acid (6) films were the objects of this research; $10 \mathrm{mg}$ of samples (1-6) were dissolved into $1 \mathrm{ml}$ of acetone forming a saturated solution. The surfaces of $\mathrm{Si} \mathrm{n}$-(100) substrate, KEF $\sim 0.5 \mathrm{Ohm} * \mathrm{~cm}\left(\sim 1 * 10^{16} \mathrm{~cm}^{-3}\right)$, were hydrothermally oxidized at $\mathrm{T}=500{ }^{\circ} \mathrm{C}$ for several hours. The $\mathrm{SiO}_{2}$ film thickness was a beat different for all the substrates that is why it was measured for each sample. Later $\mathrm{SiO}_{2} / \mathrm{Si}$ substrates were partially immersed into saturated acetone solution of triazenes (1-5) as well as into solution of 1anthraquinone phosphonate acid (6) and pulled slowly.<smiles>O=C1c2ccccc2C(=O)c2c(N=NCCO)cccc21</smiles>

[10]<smiles>O=C(O)c1ccc(N=Nc2cc(S(=O)(=O)O)c(N=Nc3ccc(C(=O)O)cc3)c3c2C(=O)c2ccccc2C3=O)cc1</smiles><smiles></smiles>

[11]<smiles>O=C1c2ccccc2C(=O)c2c(N=NN3CCOCC3)c(S(=O)(=O)O)cc(-n3ccnc3)c21</smiles><smiles>O=C1c2ccccc2C(=O)c2c(N=NCCO)c(S(=O)(=O)O)cc(-n3ccnc3)c21</smiles><smiles>O=C1c2ccccc2C(=O)c2c1cccc2P(=O)(O)O</smiles> 
The uniformity of deposited films and their thicknesses were measured in 3 points by spectral ellipsometry technique within the optical model shown on Tabel 1. The first point is close to the surface without film (in the bottom), second - in the center and the third is close to the top. Thicknesses are given in Tabel 2 .

Table 1 An optical model of the structures under study using the example of triazene sample №1

\begin{tabular}{|c|c|c|}
\hline 2 & triazene $\mathrm{n} 1$ point 2 & $87.688 \mathrm{~nm}$ \\
\hline 1 & $\mathrm{SiO}_{2}$ & $25.172 \mathrm{~nm}$ \\
\hline 0 & $\mathrm{Si}$ & $0.45 \mathrm{~nm}$ \\
\hline
\end{tabular}

Table 2

$\mathrm{SiO}_{2}$ film thickness and the thickness of triazenes on Si substrate

\begin{tabular}{|c|c|c|c|c|c|c|}
\hline \multirow{3}{*}{ Simple } & \multicolumn{3}{|c|}{$\mathrm{SiO}_{2}$ thickness, $\mathrm{nm}$} & \multicolumn{3}{|c|}{ Film thickness, $\mathrm{nm}$} \\
\cline { 2 - 7 } & Point & Point & Point & Point & Point & Point \\
& 1 & 2 & 3 & 1 & 2 & 3 \\
\hline 1 & 24.7 & 24.7 & 24.7 & 87.9 & 82.8 & 80.5 \\
\hline 2 & 25.3 & 24.9 & 34.3 & 176.3 & 176.7 & 148.5 \\
\hline 3 & 24.2 & 21.8 & 24.2 & 2.1 & 0.37 & 3.4 \\
\hline 4 & 26.0 & 26.3 & 21.1 & 6.4 & 6.4 & 8.1 \\
\hline 5 & 18.5 & 18.5 & 18.7 & 0.12 & 2.1 & 7.8 \\
\hline 6 & 35 & - & - & 1.2 & - & - \\
\hline
\end{tabular}

Analysis of film surface morphology.

The film surface structure was studied by microhardness tester NEXUS A412 set with 100x and $400 \mathrm{x}$ zoom setup. With $100 \mathrm{x}$ zoom the picture size is $450 \times 450 \mu \mathrm{m}$ and with $400 \mathrm{x}$ is $100 \mathrm{x} 100 \mu \mathrm{m}$. Fig. 1-6 are the expanded photos of film samples.

\section{Results and discussion}

The spherical particles of different size were clearly recognized while analyzing the microphotos of the film surfaces. This indicates an uneven distribution of particles on the surface of the substrate. This is caused by different factors: the absence of stable relation between substrate and some anthraquinone macromolecules; packaging defects that might appear during coalescence of particles. The reason is a violation of the alternation of molecular planes during merging. Packaging defects might appear even in the spots of contact between particles and substrate (Fig. 1-2) possibly because of the plastic deformation effect of the prepared films.

This allows us to make an assumption: the growth of films on hydrothermally oxidezed $\left(>500{ }^{\circ} \mathrm{C}\right)$ substrates is a result of triazene ions absorbation

$\left(-\mathrm{N}^{1}=\mathrm{N}^{2}-\mathrm{N}^{3}<\leftrightarrow^{-} \mathrm{N}-\mathrm{N}=\mathrm{N}^{+}<\right)$. This ions interact with $\mathrm{SiO}_{2}$ and form primary settling centers. This structural resonance (scheme 1) is also an attribute of polar aproton solvents. It's caused by transition state of sp-hybridized nitrogen and decreasing order of $\mathrm{N} 1=\mathrm{N} 2$ bond [13]. That's why aceton was picked as main solvent to grow the films.

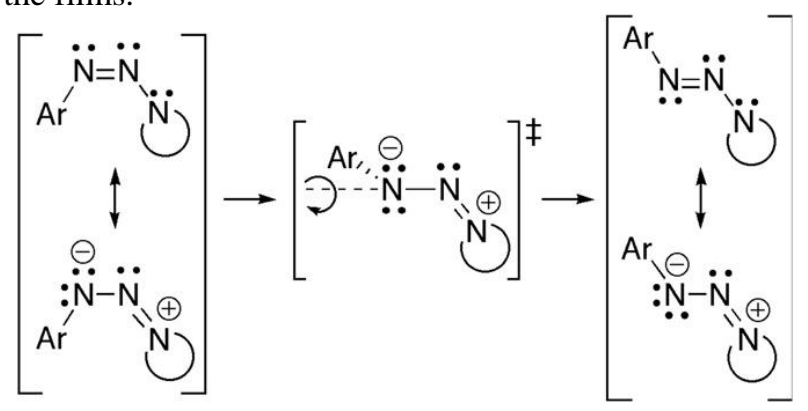

Scheme 1. Inversion mechanism.

The presence of an aromatic substituent with hydrogen near the nitrogen $\left(\mathrm{N}^{3}\right)$ in particular triazene 4 can lead to the formation of isomeric forms which will

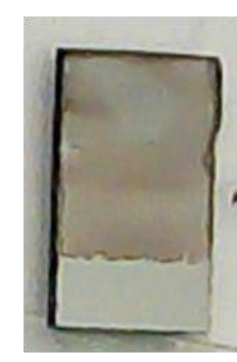

Films 1<smiles>O=C1c2ccccc2C(=O)c2c(N=NCCO)cccc21</smiles>

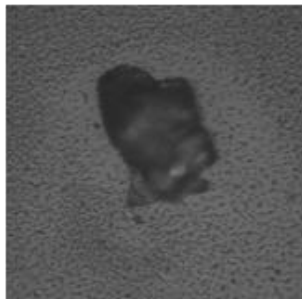

$a-\times 400$

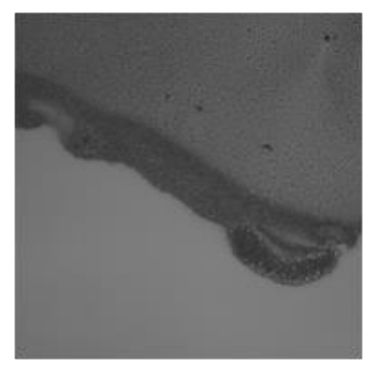

c $-\times 100$
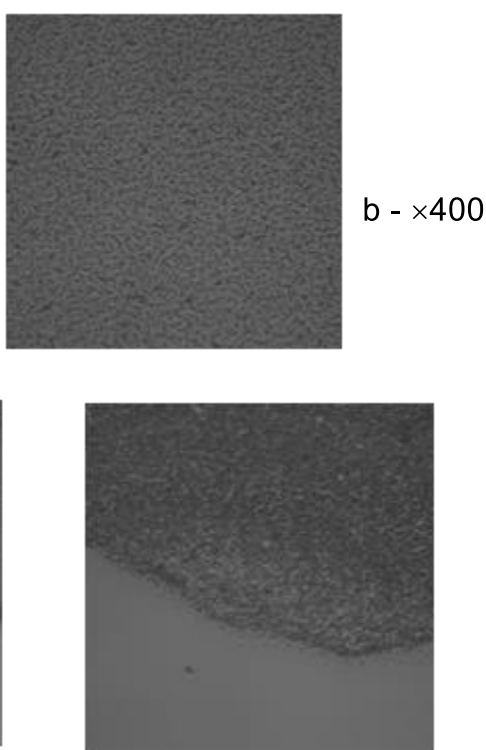

c $-\times 400$

Fig.. 1. Microphotos of film surface 1: a - formation of a big particle in the top corner $>170 \mathrm{~nm}$.; $\mathrm{b}$ - spherical particles in the center of the film; $\mathrm{c}$ - image of the film border. 


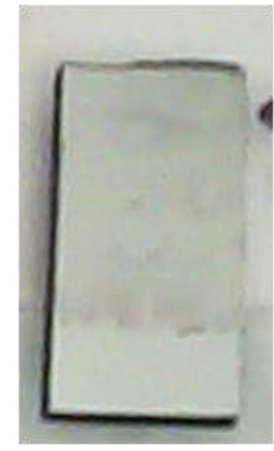

Films 2

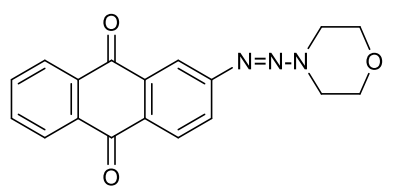

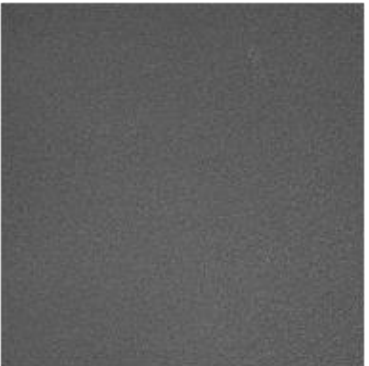

$a-\times 100$

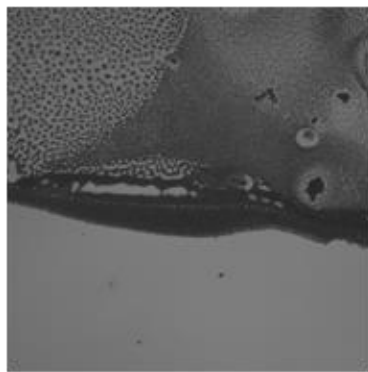

$b-\times 100$

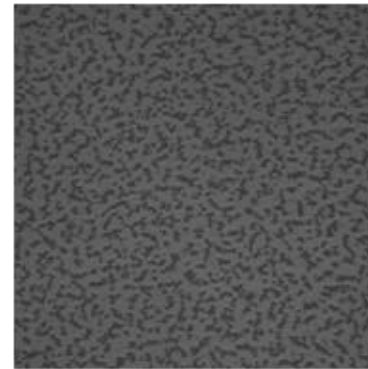

$a-\times 400$

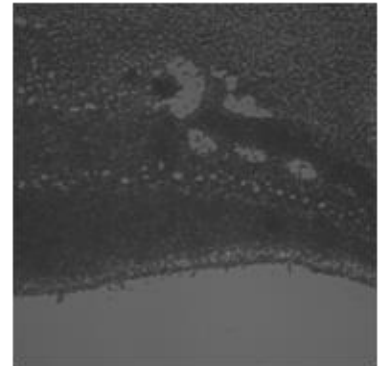

$b-\times 400$

Fig.2. Microphotos of film surface 2: a - spherical particles in the center of the film; $\mathrm{b}$ - image of the film border.<smiles>O=C1c2ccccc2C(=O)c2c1c(N=NCCO)c(O)c(O)c2-n1ccnc1</smiles>

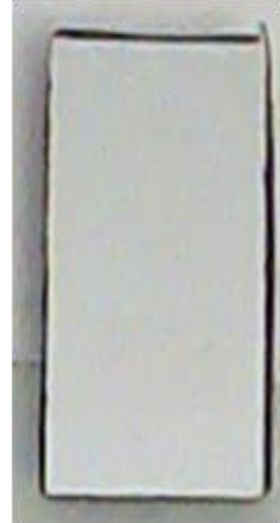

$a-\times 400$

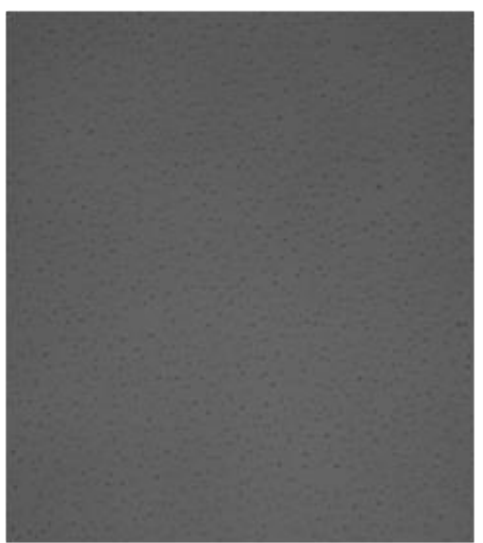

Fig. 3. Microphotos of film surface 3: a - spherical interspersions of triazene.

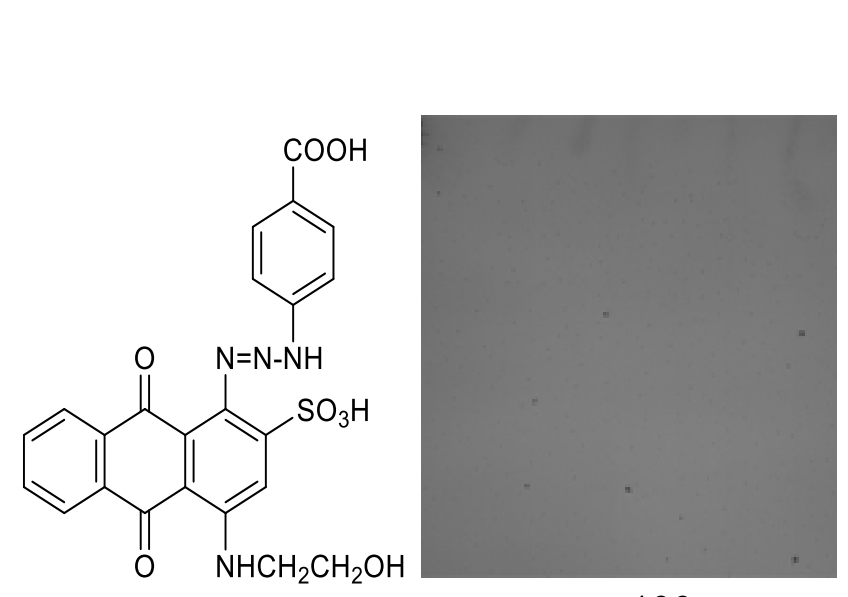

$a-\times 100$

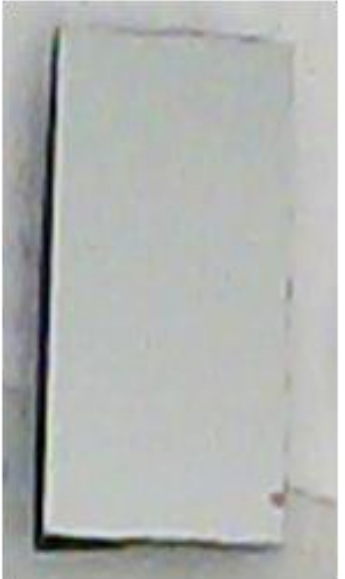

Films 4

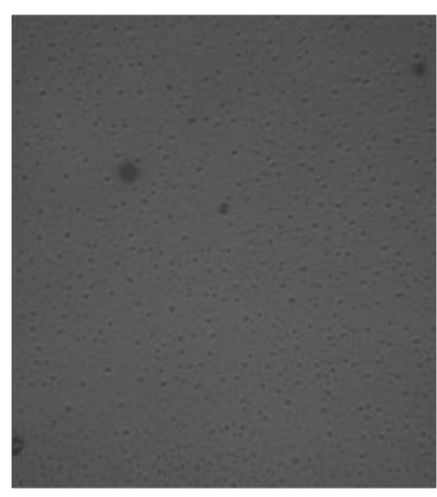

$a-\times 400$

Fig. 4. Microphotos of film surface 4: a - spherical interspersions with lonely agglomerations. 
<smiles>O=C1c2ccccc2C(=O)c2c(N=NN3CCOCC3)c(S(=O)(=O)O)cc(-n3ccnc3)c21</smiles>

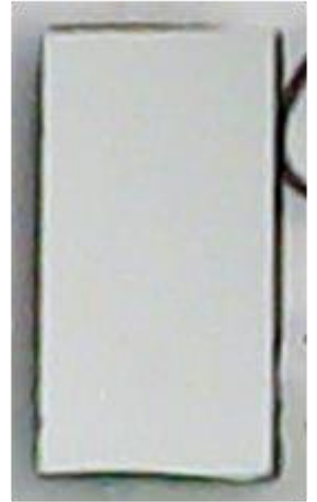

Films 6<smiles>O=C1c2ccccc2C(=O)c2c1cccc2P(=O)(O)O</smiles>

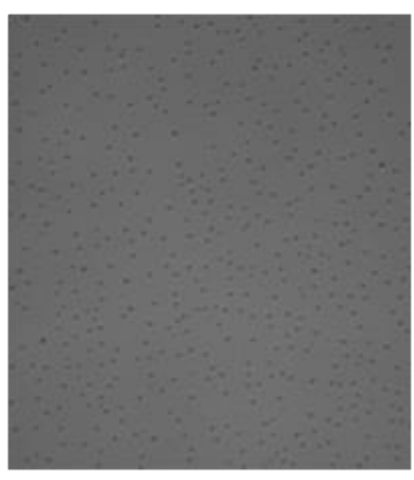

$a-\times 100$

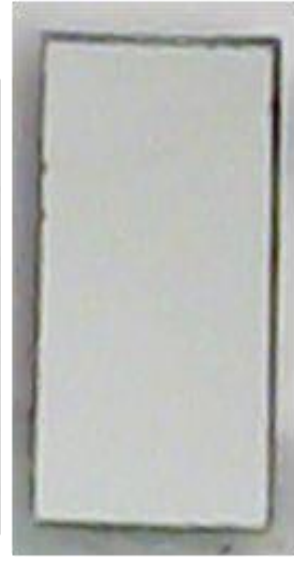

Films 5

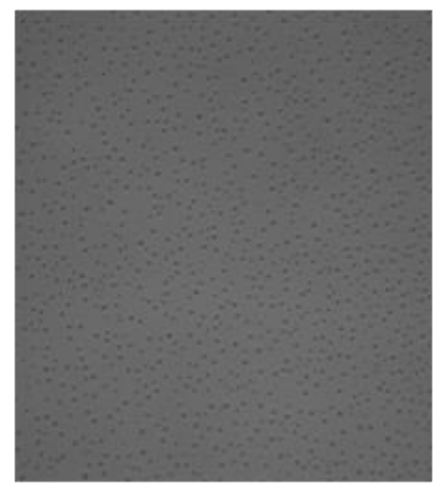

$a-\times 400$

Fig. 5. Microphotos of film surface 5: a - spherical interspersions of agglomerates.

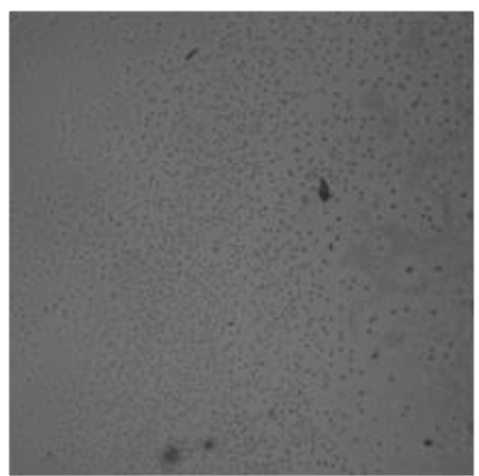

$a-\times 100$

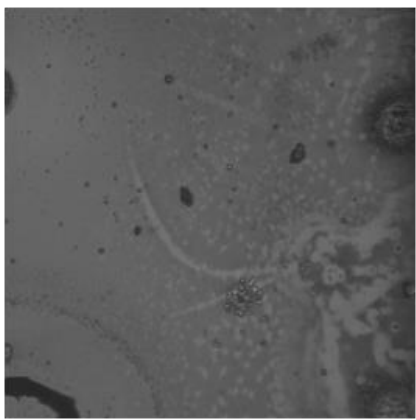

b $-\times 100$

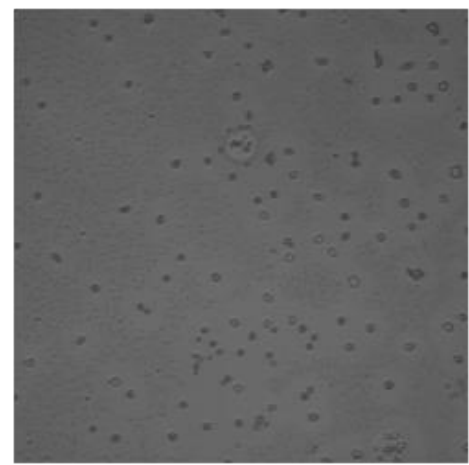

a $-\times 400$

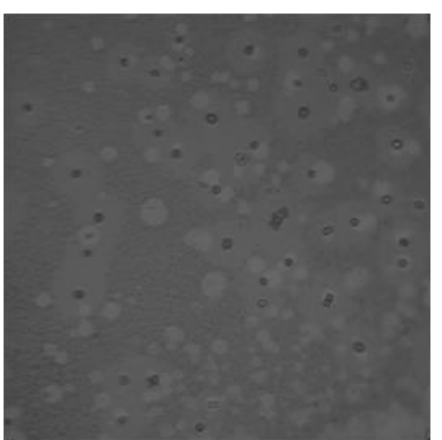

$b-\times 400$

Fig. 6. Microphotos of film surface 6: a - spherical interspersions of particles in the bottom of the fill; $\mathrm{b}-$ big particles with different orientation and order.

impede the charge inversion between the nitrogen atoms (Scheme 2). As a result triazene will be applied uneveny on the substrate and the coalescence of particles will appear (Fig. 4).

The presence of aromatic heterocyclic moiety in particular imidazole in the 4th position in samples 3 and 5 , further reduces the film thickness $(0.12-7.8 \mathrm{~nm})$, the increase was observed only at the top point of the film (Fig. 3b), which in our opinion is the result of different orientation of anthraquinone molecular planes and imidazole residue. Instead, 1-anthraquinonophosphonic acid (6) practically did not form a film on the substrate surface due to the absence of a triazene group; only $\sim 1 \mathrm{~nm}$ particles were observed at the film boundary.
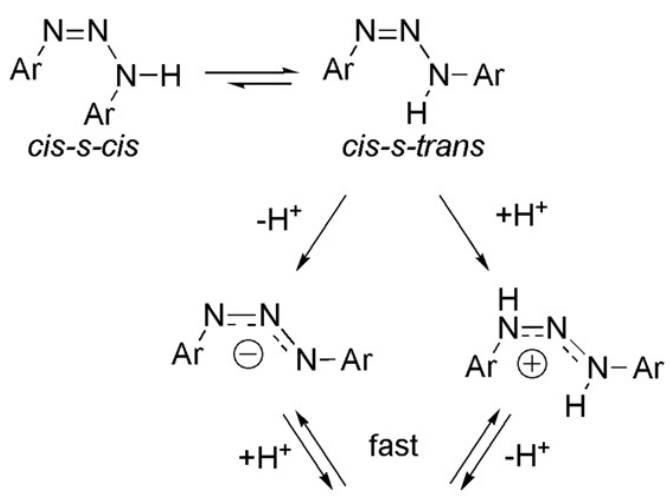

$$
\mathrm{ArHN}^{-} \mathrm{N}_{\mathrm{N}^{-}}-\mathrm{Ar}
$$

Scheme 2. Cis-trans isomerization of 1,3-aromatic triazenes in aprotic polar solvents [14-15]. 


\section{Conclusions}

The morphology and peculiarities of triazene films deposition on oxidized silicon substrate were investigated by magnification and fixation of the image with a microhardness meter. The thickness of the film, its uniformity and the number of agglomerates depend on the type of triazene. Surface preparation has a significant effect, so an increase in hydrophilicity (silicon oxidation) improves the deposition conditions of anthraquinonebased triazines.

\section{Acknowledgements}

The work was carried out with the financial support of the Ministry of Education and Science of Ukraine (Project No. 0119U103131).
Shupeniuk V.I. - Junior researcher of the Department of Chemistry of the Environment and Chemical Education. Mamykin S.V. - Ph.D (Physics and Mathematics), Head of the Department of Polariton Optoelectronics and Nanostructure Technology.

Taras T.N. - Ph.D (Chemistry), Head of the Department of Chemistry of the Environment and Chemical Education.

Matkivskyi M.P. - Ph.D (Technical), Associate Professor of the Department of Chemistry of the Environment and Chemical Education.

Sabadakh O.P. - Ph.D (Chemistry), Junior researcher of the Department of Chemistry of the Environment and Chemical Education.

Matkivskyi O.M. - Ph.D (Physics and Mathematics), Senior Researcher of the Department of Physics and Chemistry of Solid State.

[1] L. Rapp, A.K. Diallo, S. Nenon et al., Thin Solid Films 520, 3043 (2012) (https://doi.org/10.1016/j.tsf.2011.10.159)

[2] S. Kumar, B. Lies, X. Zhang et al., Polymer International 68(8), 1391 (2019) (https://doi.org/10.1002/pi.5834).

[3] K.G. Yager, C.J. Barrett, Curr. Opin. Solid State Mater. Sci. 5, 487 (2001).

[4] T. Lippert, M. Hauer, C.R. Phipps, A. Wokaun, Appl. Phys. A 77, 259 (2003) (https://10.1007/s00339003-2111-y).

[5] P. Zhao, Z. Zhang, P.J. Wang, D.S. Liu, Physica B 404, 3462 (2009) (https://doi.org/10.1016/j.physb.2009.05.036).

[6] G. Griffini, J. D. Douglas, C. Piliego et al., Adv. Mater 23, 1660 (2011) (https://doi.org/10.1002/adma.201004743).

[7] L. Hai-Ying, L. Liang-Cai, Synthetic Comm. 31(1), 155 (2001) (https://doi.org/10.1081/SCC100000193).

[8] Y. Zhang, H. Zhuang, Y. Yang et al., J. Phys.Chem. C 116(43), 22832 (2012) (https://dx.doi.org/10.1021/jp305556u).

[9] H. Li, N.J. Li, H.W. Gu et al., J. Phys. Chem. C 114, 6117 (2010) (https://doi.org/10.1021/jp910772m).

[10] O.P. Sabadakh, T.N. Taras, E.R. Luchkevich, V.P. Novikov, Russ. J. Org. Chem. 51(2), 277 (2015) (https://doi.org/10.1134/S1070428015020244).

[11] T.M. Taras, Y.I. Dejchakivsky, V.I. Shupeniuk et al., Chem., Technol. and Application of Substances 2(1), 92 (2019) (https://doi.org/10.23939/ctas2019.01.092).

[12] V.I. Shupeniuk, T.M. Taras, O.P. Sabadakh et al., Chem., Technol. and Application of Substances 2(2), 135 (2019) (https://doi.org/10.23939/ctas2019.02.135).

[13] R. Tabone, M. Barra, Dyes and Pigments 88, 180 (2011) (https://doi.org/10.1016/j.dyepig.2010.06.006).

[14] M. Barra, N. Che,n J Org. Chem. 65, 5739 (2000) (https://doi.org/10.1021/jo0005991).

[15] H. Zhang, M. Barra, J. Phys. Org. Chem. 18, 498 (2005) (https://doi.org/10.1002/poc.900). 


\title{
В.І. Шупенюк ${ }^{1}$, С.В. Мамикін ${ }^{2}$, Т.М. Тарас ${ }^{1}$, М.П. Матківський ${ }^{1}$, О.П. Сабадах ${ }^{1}$, О.М. Матківський ${ }^{1}$
}

\section{Структура та морфологія плівок триазенів на основі антрахінону на кремнісвій підкладці}

\author{
${ }^{I}$ Прикарпатський національний університет імені Василя Стефаника, Івано-Франківськ, Украйна, \\ vasyl.shupeniuk@pnu.edu.ua \\ ${ }^{2}$ Iнститут фізики напівпровідників імені В.С. Лашкарьова НАН, Київ, Украӥна, smaтуkin@gтаil.com
}

Підібрано оптимальний метод нанесення триазенів антрахінонової серії на кремнієву підкладку для одержання плівок нанометрового розміру, які можна використати як діалектричні ароматичні буферні шари. Дослідження морфології плівок триазенів показало, що на фоні змінної товщини шарів триазенів наявні делокалізовані глобулярні мікроутворення антрахінонових макромолекул в основному сферичної форми. На оксидовану поверхню підкладки триазени наноситься краще, ніж на ті, що без оксиду. Це пов'язано з розподілом електронної густини в триазенах, що створює додаткову систему спряження 3 $\mathrm{Si} / \mathrm{SiO}_{2}$, а наявність об'ємних ароматичних замісників погіршує рівномірність нанесення плівки і зменшує іiї товщину.

Ключові слова: плівки триазенів, антрахінон, електронна густина, антрахінон-2-діазоній, кремнієва підкладка. 